\title{
D110＼cjkstart水噴流による気泡キャリーアンダー
}

\section{Carry-under of bubbles by impinging jet}

$\begin{array}{rllrlll}\text { 正 大竹 } & \text { 浩靖 } & \text { (工学院) } & \text { 正 } & \text { 小泉 } & \text { 安郎 } & \text { (信州大) } \\ \text { ○学 大塚 } & \text { 智彦 } & \text { (工学院) } & & \text { 原口 } & \text { 直樹 } & \text { (工学院) }\end{array}$

Hiroyasu Ohtake, Tomohiko Ohtsuka, Naoki Haragutchi, Kogakuin University, 1-24-2,Nishishinjuku,Shinjuku-ku,Tokyo

Yasuo Koizumi, 3-15-1, Tokida, Ueda-shi, Nagano

\begin{abstract}
The carry-under that bubbles are rolled into a pool when a liquid column/jet or a liquid film on a wall flows down into a liquid pool was examined. When the flow rate was low, the liquid column disrupted into liquid lumps. A dent was formed on the pool surface by the liquid lumps hitting the pool surface. Gas in the dent was pulled down into the liquid pool. The disruption of the jet was well explained with the Kelvin-Helmholtz instability. As the flow rate was increased, the surface of the liquid jet became smooth and the carry-under. ceased. As the flow rate was further increased, the surface of the liquid jet became disturbed condition. By the disturbance dents were formed periodically on the pool surface and gas in the dents was pulled down into the pool with the jet flow. The penetration of the bubbles into the pool became deep.
\end{abstract}

\section{Key Carry-Under, Air entrainment, Water jet, Void fraction)}

1. 緒言 液体噴流が液体プール表面に注がれるとき、周囲 の気体を巻き込む現象は日常よく見かける現象であり、気 泡キャリーアンダと呼ばれ、いくつかの研究例がある。(1), (2)液体プール内に強い流れがあり、摚汼混合状態にある場 合、さらに液体プールから外部への流出流がある場合、プ 一ル内に巻き込まれた気泡が流れに乗って運ばれていくこ とが起こりうる。軽水炉や高速增殖炉において、このよう な気泡が冷却材中に混入した場合、循環力低下や炬心反忘 度に大きな影響を及ぼす可能性がある。本研究では、この 現象に関する基礎研究として、静止プール内に液柱が流下 する場合のキャリーアンダ現象について調べている。未解 明なこの現象の発生について、流下液柱状況の視覚的観察 結果をもとに述べる。

\section{2. 実験装䈯及び実験方法}

\section{実験装置の概要図を Fig. 1}

に示す。作動流体には室温水

道水を用いた。テスト容器で ある透明アクリル製水槽の大 きさは $600 \mathrm{~mm} \times 600 \mathrm{~mm}$ $\times 600 \mathrm{~mm}$ である。ポンプか ら送り出された水は、浮き子 式流量計を通り、ノズルから 鉛直下向きに流出し、液柱と なってプールへ流入する。出 ロノズルはストレートタイプ であり、内径 $5 \mathrm{~mm}$ 、ストレ 一ト部長さ $10 \mathrm{~mm}$ である。プ 一ルからポンプへ気泡吸い込み が生じないよう水槽内には仕切 り板が挿入されている。またポ

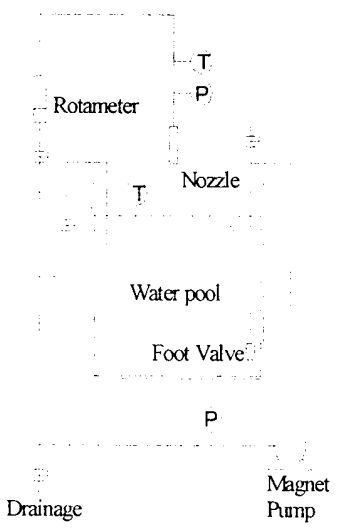

Fig. 1

Experimental apparatus
ンプ振動がノズルから流出する液柱性状に影響を与えない ようフレキシブルチューブを用いてポンプとノズル配管采 は接続されている。一定流量でノズルから噴流が流下する 状態で、噴流界面状況をノズル出口から水面まで位置を変 えて高速度カメラにて 500〜6000 frames/sで撮影した。 プール内気泡巻込み状況は水槽側面から高速度カメラにて $500 \mathrm{frames} / \mathrm{s}$ で撮影した。水面に噴流が突入する状況は、 水槽内に気泡遮蔽板を入れ噴流突入部近傍が観察できるよ
うにし、高速度カメ

ラにて 4000

frames/s で撮影し

た。尚、プール水の

温度は $K$ 型熱電対に

て測定し、恒温水槽

中にコイル状にした

配管の一部を沈める

ことで一定温度に制

御した。

3. 実験的考察 3.1 気泡

到達深度 流量 $0.1 \sim 5.0$

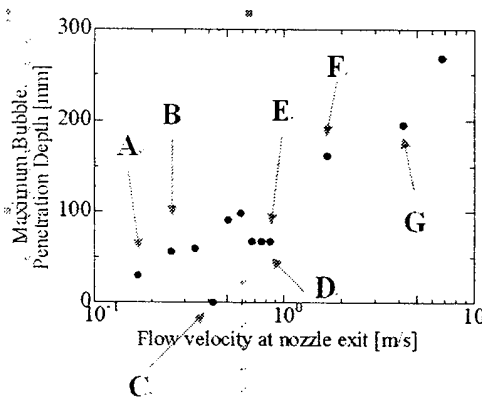

Fig.2 Maximum Bubble penetration Depth $\mathrm{l} / \mathrm{min}$ (ノズル流出時流速 $0.085 \sim 4.244 \mathrm{~m} / \mathrm{s}$ )の範囲で行った、 液柱流量とプール内気泡最大巻き込み深度の関係を Fig. 2 に示す。高速度カメラ $500 \mathrm{frames} / \mathrm{s}$ で 2.14 秒間撮影した 動画から気泡の最大到達深度を測定している。Fig. 3 の A 〜Fには、プール水面に突入する液柱の状況とプール内気 泡巻き込み状況を合わせて示した。Fig. 3 中のアルファベ ットは、Fig. 2 中のものと対応している。Aのように流量 が少ない場合、液柱は途中で途切れ液滴状となり、プール 水面に突入する。ある程度の体積と速度をもつ液滴が飛び 込むと、プール界面に瞬間的にくぼみが形成される。これ が消え去らないうちに、更に液滴が飛び込みことによって くぼみの一部が気泡となってプール中に引き込まれる。こ れの連続により気泡巻き込みが生じているようである。気 泡巻き込み深度はそれほど大きくはない。しかし B の状態 まで流量が増加すると、液中表面は滑らかなままプールへ 突入し、プール界面はほぼ平滑な状態を保つ。この状態で は、気泡巻き込みは生じなくなる。更に流量が増加し、C の状態のように噴流界面に乱れを再び伴うようになると、 気泡巻き込みは再び発生する。液柱界面には再び乱れが発 生するようになり、間久的に大きな固まりとなってプール に突入する。結果としてプール界面に大きな動摇が再び生 じるようになり、また、それにより大きな気泡塊がプール 内に引きずり込まれる。気泡はプール内で分裂しつつ下方 八押しやられ、ある深度まで至ると上昇八転じ、プール界 面から離脱するようになる。さらに流速が上がり、 $\mathrm{E}, \mathrm{F} の$ 
状態になると、噴流界面の状態はより複雑になり、プール 界面の噴流突入部には気泡ポケットがほぼ常に形成され、 気泡量も著しく增大していく。
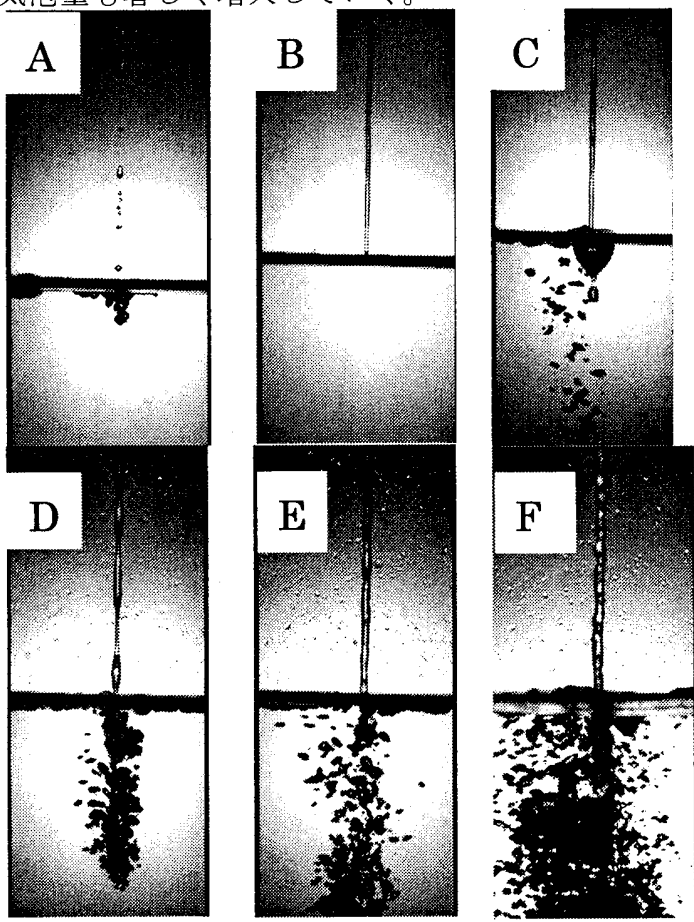

Fig3 State of Jet flow and Carry-under 3.2 気泡巻き込みのメカニズム 実験結果の観察から巻 き込みメカニズムの簡単なモデルを考察した。気泡の巻き 込みは Fig.4に示すようにいくつかのプロセスを経て発生 する。まずプール界面に液滴もしくは噴流の膨張部が飛び 込む(A)。するとプール界面に瞬間的にくぼみを形成する (B)。これが収縮し終わらない内に、更に後続の液滴もしく は噴流膨張部が飛び込むと、くぼみの底部にさらにくぼみ を形成する $(\mathrm{C})$ 。場合いによってはこれがプール中に取り残 されて気泡となり、噴流の勢いによって巻き込まれていく ことになる(D)。ここで、気泡巻き込みの条件は噴流の運動 エネルギーとプール界面の表面エネルギーのバランスによ って決まると想定する。今後ここれを検討する予定である。
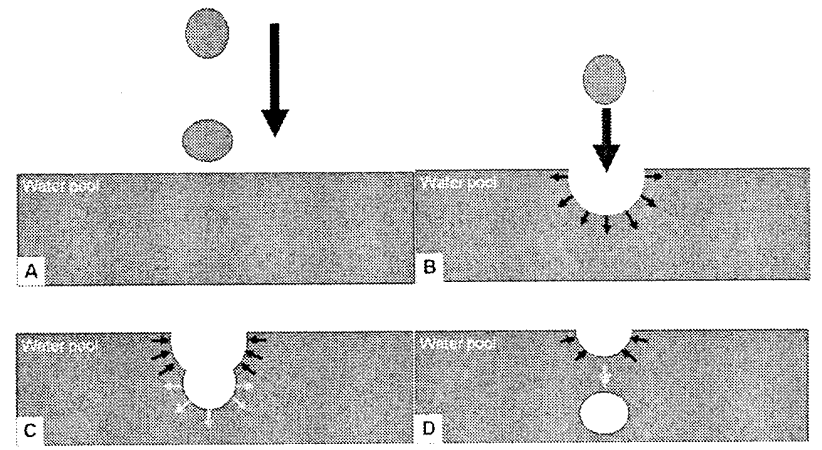

Fig.4. Mechanism of Carry-under

3.3 噴流界面の波長 噴流界面に波が生じる原因のひと つとして Kelvin-Helmholtz 不安定性が考えられる。Fig.3 中の $\mathrm{A}$ と、について以下の式で求められる Kelvin-Helmholtz 不安定性による臨界波長と、撮影画像か ら波頭速度と波の周期を得て実測した波長との比較を Fig.5,6 に示す。

$$
\lambda_{c}=\left[\frac{2 \pi \sigma\left(\rho_{l}+\rho_{g}\right)}{\rho_{l} \rho_{g}}\right]\left(u_{g}-u_{l}\right)^{-2}
$$

ここで、水の密度 $\rho_{\mathrm{l}}=1000 \mathrm{~kg} / \mathrm{m}^{3}$ 、空気の密度 $\rho_{\mathrm{g}}=$ $1.176 \mathrm{~kg} / \mathrm{m}^{3}$ 、水の表面張力 $\sigma=73.21 \mathrm{mN} / \mathrm{m}$ である。 ul はそれぞれの測定位置の噴流の平均流速であり連続の式 から求めた。また、気速 $u_{\mathrm{g}}$ は静止状態ゼロと仮定した。 Fig.5の条件は液柱が水面に到達する以前に液隗への分裂 が生じていたものである。測定された波長は K-H 臨界波長 に達しておらず、実際の液柱の分裂と詨応していない。 Fig.6 は噴流が分裂していない条件である。測定波長は、 $\mathrm{K} \cdot \mathrm{H}$ 臨界波長に至っておらず、液柱は形状を維持していた ことに相応している。しかし、界面には多くの擾乱が存在 しており、これらが気泡巻込みを促していることがうかが える。
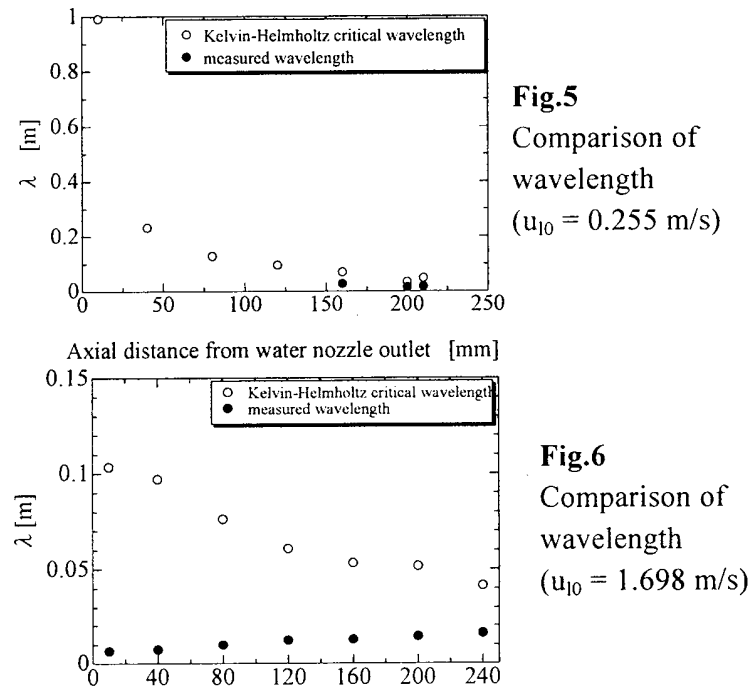

Axial distance from water nozzle outlet [mm]

4. 結言 出口径 $5 \mathrm{~mm}$ のノズルから液体プール表面に注 がれる噴流に対し、その界面の状態および気泡キャリーア ンダの様子を高速度カメラにて撮影し、キャリーアンダに ついて定性的な以下の結論を得た。（1）流量が小さく液柱 が分断し液滴状となってプールへ流下する場合、プール界 面動摇を伴い、それにより小気泡がプール内へ同伴される。 （2）流量が增し、界面に乱れを伴わず平滑な液柱となって プールへ乫入するようになると、気泡巻き込みは生じない。 （3）流量が増加し、液柱界面に大きな波が発生するように なると大きな気泡の巻き込みが生じるようになり、気泡到 達深度は増大する。（4）流量が更に増大し、噴流界面に波 ではなく不規則な乱れを伴うようになると、気泡巻き込み 深度、量は激しく增大する。(5) キャリーアンダが起こら ない範囲よりも高い流速域では、液柱の分断に

Kelvin-Helmholtz 不安定性が影響を与えている。低い流速 域では他の原因によって噴流の乱れ、分裂が発生している。 （6）観察結果として、プール界面突入時の液柱界面状況が キャリーアンダ発生と気泡到達深度に大きな影響を持つ。 <参考文献 > 1. F. Bonetto and R. T. Lahey, Jr "An experimental study on air carryunder due to a plunging liquid jet" International Journal of Multiphase Flow. (1993) Vol. 19, Issue 2, pp. 281-294.

2. By YONGGANG ZHU, HASAN N.OGUZ AND ANDREA PROSPERETTI, "On the mechanism of air entrainment by liquid jets at a free surface" J. Fluid Mech. (2000), vol. 404, pp. 151-177. 